\title{
The Architecture of Liberalism and the Origins of Carceral Democracy
}

\begin{abstract}
A throng of bearded men, in sad-colored garments and gray, steeple-crowned hats, intermixed with women, some wearing hoods, and others bareheaded, was assembled in front of a wooden edifice, the door of which was heavily timbered with oak, and studded with iron spikes. The founders of a new colony, whatever Utopia of human virtue and happiness they might originally project, have invariably recognized it among their earliest practical necessities to allot a portion of the virgin soil as a cemetery, and another portion as the site of a prison. In accordance with this rule, it may safely be assumed that the forefathers of Boston had built the first prison-house. . . . Certain it is, that, some fifteen or twenty years after the settlement of the town, the wooden jail was already marked with weather-stains and other indications of age, which gave a yet darker aspect to its beetle-browed and gloomy front. The rust on the ponderous iron-work of its oaken door looked more antique than any thing else in the new world. Like all that pertains to crime, it seemed never to have known a youthful era. Before this ugly edifice, and between it and the wheel-track of the street, was a grass-plot ... which evidently found something congenial in the soil that had so early borne the black flower of civilized society, a prison.
\end{abstract}

-NATHANIEL HAWTHORNE, “THE PRISON DOOR,"

THE SCARLET LETTER

"Buried how long?"

The answer was always the same: "Almost eighteen years."

"You had abandoned all hope of being dug out?"

"Long ago."

"You know that you are recalled to life?"

"They tell me so."

"I hope you care to live?"

"I can't say."

- CHARLES DICKENS, TALE OF TWO CITIES 
The prison house door was an icon in nineteenth-century political life. "Heavily timbered with oak," the door was "studded with iron spikes" because it represented passage from the world of the free to a place beyond civic status. It was a place shrouded in mystery beyond the public eye, and its door looked "more antique than anything else in the new world." The prisons of Hawthorne's time were designed to resemble medieval castles, and they symbolically reached back from the time of "modern" democracy and rationality in the nineteenth century and drew the language of tyranny and despotism into the framework of American governance. As part of an iconography of civil death, the door was the state's representation of a transformative departure to a place without political status. In recording freedom's inversion in the prison house door, the state left open, in the power of the doorway, the possibility of a return - of being "recalled to life" from the space beyond. Because the door and the building behind it were imagined as a kind of legal border, the prison became, as a matter of law, a crossing into a particular kind of space. ${ }^{1}$

When Hawthorne wrote about colonial prisons with "iron rivets," he used them as a site for exploring the gothic institutions of his own time. When he wrote The Scarlet Letter in 1850, the colonial prisons it depicted had been condemned as antiquated and antirepublican institutions and had been replaced by the first generation of American prisons, which had already failed and been replaced by another set of gothic penal architectures in the late 1820 s and early 1830s. Nearly every state penal institution built between 1829 and 1890 drew on the idea of the carceral gothic, including Pennsylvania, New York, New Jersey, Tennessee, Kentucky, Ohio, West Virginia, Kansas, Arkansas, Maryland, Louisiana, Illinois, Indiana, South Carolina, North Carolina, Michigan, and Missouri. When the federal government created a class of federal prisoners beginning in 1787 , gradually increasing the number of federal crimes and therefore federal prisoners over the course of the nineteenth century, it housed federal prisoners in gothic state institutions. In the time before Leavenworth, a federal prison system existed without a building, as the nation's earliest prisoners were sent to gothic institutions in Pennsylvania, New York, New Jersey, Illinois, Ohio, West Virginia, Missouri, and Kansas.

What was gothic about the legal architecture of civil death was the possibility of eternal enclosure-a horror from which there was no return. One of the central problems with these prisons, according to the earliest reports of federal prison administrators, was that they relied on the idea of state violence against the body of the prisoner. The gothic prisons were symbols of that violence and the forms of infamy they assigned to the body. As a kind of degraded status bestowed on that body when the state defiled the prisoner through physical violence, infamy was inherited in the common-law tradition and defined the status of the prisoner in the United States. William Blackstone's Commentaries on the Laws of England recorded the way in which infamous punishments were connected to "ignominy" 
and included the shame of "public labor, in the house of correction or otherwise, as well as whipping, the pillory, or the stocks." ${ }^{2}$ When it marked that body with degradation, the state attached "infamation" to the body for life, creating a kind of gothic script and a source of state terror beyond escape. ${ }^{3}$ This form of state violence, which assigned the status of infamia juris (infamy of law), was distinct from the legal mark left behind when crimes were considered infamous in fact (infamia facto).

The federal prison system had its origins in the state institutions that assigned infamia juris to the body. The earliest government reports on federal prisoners housed in state institutions index the violence of gothic prisons and present the formation of a federal system as the answer to that structure of violence. As detailed in the 1885 reports, New Jersey was built in an Egyptian gothic style, and punishment was "by the dungeon, chaining down, and tying up." ${ }^{4}$ In Missouri's stone castle, which held hundreds of federal prisoners over the years, the standard practice was "flogging with the raw-hide." ${ }^{5}$ Large numbers of federal prisoners were also sent to Indiana, where the dark cell was used with the cat, "a rubber whip handle with five strands of raw hide attached to it." ${ }^{\text {Illinois practiced forced }}$ standing with "the hands put through the grated door and handcuffed on the outside." 7 Federal prisoners in Ohio's state prison experienced "ducking," which involved a "stream of water directed from a hose with some force upon the naked person," and "the slide," an "arrangement by which the convict is drawn up by the wrists, handcuffed till he stands on tip toe." In West Virginia, where substantial numbers of federal prisoners were held, discipline was governed by the lash, the shoo fly (a "frame work made of wood with slots for the prisoner's legs, hands and wrists") and the bull ring (a "ring fastened in the wall considerably above the floor to which the prisoner is drawn by his wrists"). ${ }^{9}$ Although much of the federal report is critical of this violence, it is acknowledged as a routine part of the prison's design - there are dungeons, chains, and medieval devices of torture in an architecture that is repeatedly described as antique. In these shared jurisdictions of state and federal power, gothic prisons were ideas about mass incarceration in the way that they assigned civil death to a mass of bodies in buildings that stood for a century.

As part of a larger theory of the carceral state, the gothic prisons that dotted the landscape by the time of Hawthorne's writing used the revival idiom of the medieval castle to build an argument about a form of state that was beyond and without time. The timelessness of prison architecture normalized gothic citizenship in political memory, as the castle was a symbol of that which remained despite decaying grounds and the end of monarchy. The prison in Hawthorne's tale, the "black flower of civilized society," was "never to have known a youthful era" because the prison was part of a memory of justice that appeared to be endless. It was the gothic prison's appearance of timelessness that gave it a sense of permanence and common sense, since timeless institutions can be taken for granted as naturalized 
features of the landscape. When Hawthorne drew the reader's attention to prison architecture and the prison house door, he challenged the naturalization of iron rivets as symbols of the state's right to deprive the citizen of the body in the gothic prison and suggested that prison reform was an attempt to redesign an institution that could not be repaired.

Despite the gothic prison's relationship to the masses and its place in the history of a nationalized prison system, the written history of US punishment has largely depoliticized the nineteenth-century carceral gothic and obscured the arguments at the heart of its design. The study of prison architecture has generally focused on the internal organization of time and space rather than on the buildings' outward appearance. ${ }^{10}$ The prison's meaning as a cultural artifact has escaped cultural inquiry in part because of architecture's turn away from the "fortress school" and its subsequent recasting as a mistaken and expensive period in the prison's history. ${ }^{11}$ This echoed the state's narrative. By 1949, the director of the Federal Bureau of Prisons described the gothic generation of American prisons as "outmoded, obsolete shells and cages."12 The Bureau of Prisons Advance Planning Unit recommended that these gothic relics of another era be replaced by highly securitized institutions whose outward appearances were designed to draw less attention. ${ }^{13}$ What is obscured in the depoliticization of the gothic is how the American prison came to be shrouded in intrigue, superstition, and terror because it drew on the power of the democratic imagination.

This chapter traces the history of the federal prison system to the gothic institutions of the nineteenth century in order to make visible the form of gothic governance that Leavenworth would eventually conceal. As the brick-and-mortar manifestation of the American penal state, Leavenworth abandoned the gothic but entrenched and concealed the legal architecture of civil death in American political culture. By the time the federal prison looked like democracy in 1896, the state's carceral capacity was already in place as an intergovernmental form of power. Both state and federal regimes of punishment coexisted in prison towns that dotted the landscape, and they relied on local ideas about carceral democracy long before Leavenworth emerged as the flagship institution of a federal prison system. This chapter examines how these castles and fortresses came to "look like" prisons in the American imagination and historicizes the carceral gothic as a form of common sense. The chapter begins with John de Haviland's original vision of the carceral gothic and the changing meanings of "the gothic" in narratives of freedom, equality, democracy, and status. In moving from the carceral gothic to the carceral state, the chapter offers a study of mass incarceration as an idea inscribed on the building. It works to denaturalize the prison's relationship to freedom in a state that has always been carceral and to contextualize the prison as an icon at the center of a complex legal and cultural relationship that was enshrined in the prison house door. 


\section{THE FORTRESS SCHOOL AND THE GOTHIC IMAGINARY}

The gothic prisons of Hawthorne's century were built between the 1790s and the 188 os as monuments to a certain kind of state. The carceral gothic was expressed in the thick and arched iron doorways that were entrances to a lost civic status and in the castellated features of fortified turrets and embattled parapets. The medieval towers that hovered above the walls drew the eye to a door with warnings etched on the surface of the building. The entrance to the Pennsylvania prison at Philadelphia, the original gothic institution in the United States, was decorated by a disproportionately large iron doorway. Kentucky inscribed above its arch Dante's depiction of the entrance to the gates of hell: "Abandon Hope, All Ye That Enter Here."14 Missouri's prison designers used the image of the clock at the top of the gothic facade to express the importance of time in the meaning of state deprivation. How did these monuments come to define the shape of punishment in the United States?

As the self-described "original architect of the system," the British-born architect John de Haviland inspired a whole generation of American prisons. ${ }^{15}$ Beginning with Eastern State in Pennsylvania, Haviland's "heavy and gloomy Gothic" became part of the foundation of state prison systems across the nation. Haviland built prisons in New Jersey, Arkansas, Missouri, and Rhode Island and drew unused plans for a prison in Louisiana. ${ }^{16}$ At the local level, he built most of the county jails in Ohio and Pennsylvania and New York, including the infamous Tombs, and he was commissioned to prepare "standard models" for the Prison Discipline Society as part of a nationwide project of jail reform. ${ }^{17}$ In his journals, Haviland imagined scaling that project to county governments across the nation, charging $\$ 65,000$ for a gothic facade, $\$ 60,000$ for one in the Egyptian style, and $\$ 55,000$ for something Roman. ${ }^{18}$ His style of building jails and prisons established a tradition in prison architecture and a customary way of expressing the political function of the building. Three hundred prisons around the world were eventually built like gothic castles. ${ }^{19}$

The carceral gothic tradition was defined by a certain relationship between the prison's inside and outside. In marking this relationship, the revival of gothic castles as prisons was designed to make an impression on an audience. ${ }^{20}$ Haviland came out of a tradition in architecture that used space to create stark contrasts. He "rarely, if ever, took into account compositional figure-ground relationships between a structure and the space surrounding it," which made his buildings appear "removed" from their immediate environment. ${ }^{21}$ The idea of the prison as matter out of place gave it a certain visibility so that its message could continually be translated to its audience. Haviland's teacher, the British architect James Elmes, had written in 1817 that a good prison was unmistakable in this act of translation: "No one viewing this edifice can possibly mistake it for anything but a gaol ... as gloomy and melancholy as possible." ${ }^{22}$ By 1826 , the gothic tradition 


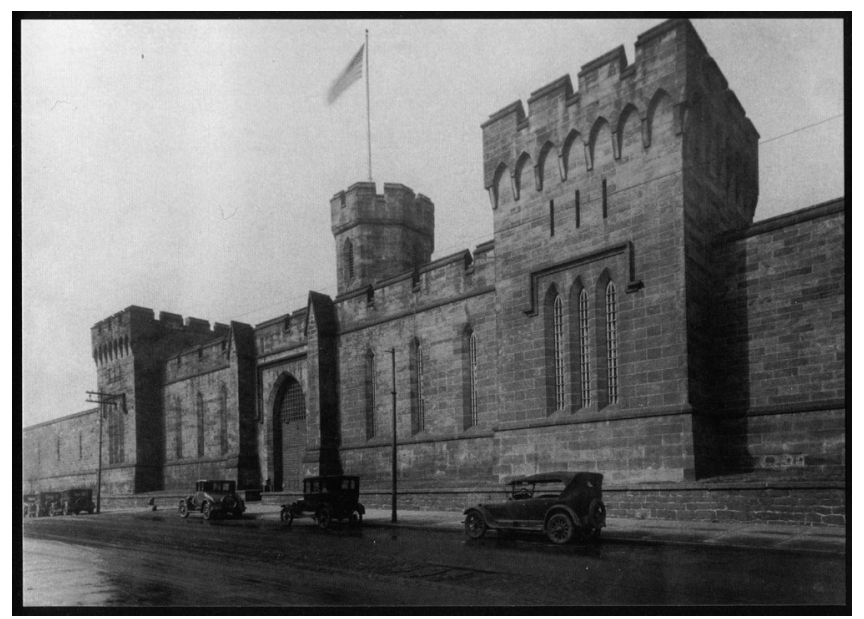

FIGURE 2. Facade of Eastern State Penitentiary, Philadelphia, 1920 s. Courtesy of Eastern State Penitentiary Historic Site, Philadelphia, Pennsylvania.

established by Elmes and his students was entered into the Encyclopedia Londonis as a matter of "no slight importance":

It offers an effectual method of exciting the imagination to a most desirable point of abhorrence. Persons, in general, refer their horror of a prison to an instinctive feeling rather than to any accurate knowledge of their privations or inflictions therein endured. And whoever remarks the forcible operations of such antipathies in the vulgar, will not neglect any means however minute, of directing them to a good purpose. The exterior of a prison should, therefore, be formed in the heavy and sombre style, which most forcibly impresses the spectator with gloom and terror. Massive cornices, the absence of windows or other ornaments, small low doors and the whole structure comparatively low, seem to include nearly all the points necessary to produce the desired effect. ${ }^{23}$

When Haviland Americanized the carceral gothic, the impression of the prison that was created through architecture joined the idea of the state to the idea of public terror. Sounding remarkably like the door in Hawthorne's tale, Haviland's prison, with its "massive wrought-iron portcullis and double oaken doors studded with iron rivets," used a familiar image to conceptualize a gothic kind of carceral state. ${ }^{24}$ John de Haviland's designs were selected by the building commissioners of Eastern State because they evoked state terror: they wrote that "the exterior of a solitary prison should exhibit as much as possible great strength and convey to the mind a cheerless blank indicative of the misery which awaits the unhappy being who enters within its walls." ${ }^{25}$ Haviland's message, described by Benjamin Rush as a program of "successful terror," magnified and created political distance through 
the "avenue to this house." ${ }^{26}$ Rush believed that a prison, as both a mystery and an exhibit, used the space between the building and its surroundings to define the prison's structure of feeling, which meant that "the gothic" was a kind of "emotion about buildings rather than any specific way of building them." ${ }^{27}$ This textured surface of the prison was part of a speaking architecture that transcribed the meaning of the building:

Let the avenue to this house be rendered difficult and gloomy by mountains or morasses. Let its doors be of iron; and let the grating, occasioned by opening and shutting them, be increased by an echo from a neighboring mountain, that shall extend and continue a sound that shall deeply pierce the soul. ... Children will press upon the evening fire in listening to the tales that will spread from this abode of misery. Superstition will add to its horrors, and romance will find in it ample materials for fiction, which cannot fail of increasing the terror of its punishments. ${ }^{28}$

The prison's purpose, in marking out this space of transition, was not just to imprison but to bind a community of prison spectators, in Rush's words, "to the meaning of the penal process." ${ }^{29}$ In this context, prisons became "places of real terror, to those the law would terrify."30

In Haviland's gothic vision of Eastern State, prisoners would be held in solitary confinement as part of a ritual of legal burial. When Charles Dickens visited Haviland's Eastern State Penitentiary in Philadelphia in 1841, he described "black hoods" drawn over the faces of entering prisoners: "And in this dark shroud, an emblem of the curtain dropped between him and the living world, he is led to the cell from which he never again comes forth, until the whole term of imprisonment has expired. He is a man buried alive." ${ }^{31}$ It also banished the prisoner to walls beyond the city's boundaries, and prisoners who resisted total silence were punished with the use of chains and the "iron gag," a device "placed in the prisoners mouth, the iron palet over his tongue, the bit forced in as far as possible, the chains brought round the jaws to the back of the neck; the end of one chain was passing through the ring in the end of the other chain ... and fastened with a lock." ${ }^{2}$ The prisoner was then "strung up" with "the hands forced upward toward the head." ${ }_{33}$ The use of stress positions was accompanied by the practice of ducking, which "suspend[ed] the offender from the yard wall by the wrists, and drench[ed] him with water, poured on his head from buckets, in nature of a shower bath." ${ }^{34}$

The violence of Eastern State in Philadelphia is often depicted as exceptional in the sense that most of the other states chose to adopt New York's competing model of factory discipline. But New York was likewise anchored in a theory of carceral state violence. The prison hovered on a hilltop above the city, its dark and crenellated roofline framing a doorway of iron grating topped by a statue of a soldier in a prison governed by the whip. ${ }^{35}$ State law allowed prisoners to receive up to thirtynine lashes with what Gustave de Beaumont and Alexis de Tocqueville described as "an instrument that Americans call 'the cat' and [the French] call the knout." ${ }^{36}$ 
When prisoners entered the institution, the warden explained the terms of civil death: "While confined here, you can have no intelligence concerning relatives or friends. ... You are to be literally buried from the world." ${ }^{37}$ The whole regime was ratified by a New York court, which agreed that "the convict should feel his degraded situation." ${ }^{8}$ In New York, Pennsylvania, New Jersey, Illinois, Ohio, West Virginia, Missouri, and Kansas, federal prisoners were arranged into these structures of civil death as part of an intergovernmental project guided by federal oversight.

These gothic institutions of civil death, as hubs in the development of the federal prison system between 1787 and 1896, had once promised to end the dungeons of the king's justice. The federal system that emerged to challenge the structure of violence in state prisons only reinforced that violence, even as it claimed to build the prison of democracy. In what Angela Y. Davis has called the "two-hundredyear-old drama of prison reform," the carceral state imagined new iterations of an already failed institution because the prison had become central to the process of state making and the forms of loyalty and consent it required. ${ }^{39}$ The prison's association with democracy was a contradiction-it functioned as a mechanism for replacing collective power with acquiescence to a burdened citizenship always threatened by the possibility of terror without escape. If prisons were understood as places of state-sanctioned violence against the body, how were they ultimately reconciled with democratic language and thought? What was the theory of the state at the heart of the gothic nightmare?

\section{IT HAS ALWAYS BEEN A CARCERAL STATE: FROM THE CARCERAL GOTHIC TO THE CARCERAL STATE}

Gothic prisons came to make sense as carceral features of political life because they materialized terror in the language of democracy. The contradictions of carceral democracy made sense to American audiences because of the cultural meaning of the castle as a place of terror in gothic literature. The idea of a castle as a prison was familiar to American audiences through the plotlines of nineteenth-century gothic texts, which crossed boundaries, registered ghosts, and used the figure of the castle to explore the terrors of the home, the mind, and the nation through the motifs of entombment, imprisonment, and claustrophobia. ${ }^{40}$ It was the literature of contrasts, of "twisted convolutions" played out in labyrinths of winding staircases and mazes of the self. ${ }^{41}$ Gothic plotlines unfolded in buildings that decayed but lasted beyond time and inspired sublime feelings of awe through architecture: "When the walls that outlast generations crumble, the powers of time appear even more awesome." ${ }^{42}$ Because the gothic castle was a terrifying place, "prisons found their models in the Middle Ages, in the castles that to readers of Gothic fiction meant dark secrets and silent suffering." ${ }^{43}$

As the stage of the gothic tradition, castles that functioned like prisons became literary sites for exploring the contradictions of state power and the terrors of 
gothic citizenship. The prison brought together the terror and horror genres of gothic literature as distinct forms defined by an escape from terror or the horror of permanent enclosure. ${ }^{44}$ While terror gothic explored the soul's potential return from the dead, horror gothic focused on the permanence of confinement. This is part of what was symbolized in the prison house door-both the possibility of imprisonment without end and the citizen's potential return from the dead. In introducing readers to the meaning of the prison house door, the carceral gothic was a language recorded in a literary genre that was both a source of critical knowledge about the politics of confinement and a central site for the prison's normalization.

As an artifact already embedded in public culture, the prison relied for its power on the participation of its audience. Penal spectatorship made meaning of the prison, teaching the citizenry to look and then to look away-to feel something in the structure of terror that was signified in the institution's very design and then to normalize that structure as a relation..$^{45}$ The purpose of the prison was therefore to produce both terror and political distance: one was "supposed to view [the scene] from close up so that he loses his 'objective distance' toward it and is immediately 'drawn' into it." 46 The whole system worked by "transmuting fear of external power into identification with its strength and thereby stabilizing both self and the social other." ${ }^{\prime 7}$ Through penal spectatorship, the prison became part of the taken-for-granted terrain of a political culture that, as Thomas Bender has suggested, is "rarely ... subject to examination" but is "continuously enacted culturally in detail after detail of living." ${ }^{48}$ It was in the prison's details, its "images, stories, and legends," that a theory of the gothic state was articulated in the language of democracy, equality, and modern governance. ${ }^{49}$

The gothic prison's staged appearance as a democratic institution was possible because it appealed to the cultural idiom of freedom. The original Goths, who invaded Europe between the fourth and sixth centuries, were associated with selfgovernance and were celebrated for a practice of self-rule that survived Roman occupation..$^{50}$ As an idiom, "the gothic" was part of a memory of white ancestry and the history of self-rule: "Parliaments and the legal system, it was believed, were derived from gothic institutions and peoples who were free and democratic." ${ }^{15}$ The association between Gothic governance and its revival in the Western "democratic" legal tradition was also part of a conjoined memory of fit lineage and noble roots. The Goths were celebrated in an 1843 speech by George P. Marsh as "the noblest branch of the Caucasian race," and as an idea about white self-governance the revival of this past in the carceral gothic signaled that the prison was built for dignified bodies..$^{52}$

This memory of the gothic enabled an institution built on state violence to be read by its audience as an emblem of freedom. The gothic prison was imagined as a place where aristocratic bodies could avoid the taint of public violence. In Europe, nobles, clerics, and the wealthy were spared the public degradation of violence against the body and the accompanying status of infamia juris (infamy of law). 
To avoid the taint of having been touched by the state, aristocratic bodies served time not in prisons but in the towers of castles or in appointed rooms in local inns. The early idea of the prison was also then an idea about the dignified body, as a place where aristocrats avoided state violence. The British idea of prisons as places of dignity was incorporated into the laws of colonial Virginia, so that its legal tradition in 1619 did not punish "persons of quality" who were by virtue of status "not fitt to undergoe corporal punishment." ${ }_{33}$ Instead, they would be "imprisoned at the discretione of the commander \& for greater offences be subject to a fine." ${ }^{54}$

It was this idea of the prison as a dignified institution that enabled the prison's embrace by the masses despite their status as targets of mass incarceration. Because it put the poor into buildings designed for aristocrats, British prison reformers sometimes lamented the class disjuncture of building elaborate castles for the "dangerous classes." ${ }_{55}$ John Howard regretted this contradiction but recognized its utility: "The new gaols," he wrote, "having pompous fronts, appear like palaces to the lower class of people." ${ }^{56}$ In his 1892 History of Prison Architecture, John Rochester Thomas explained that prisons were easily "mistaken for palaces" by the masses. ${ }^{57}$ In the European context, the prison was evidence of a tyranny overcome by freedom: in the memory of the Bastille, the castle-prison was a place where bodies were disappeared in dungeons but where citizens stormed the building to reclaim them in the name of democracy. ${ }^{58}$ In the United States, the prison was positioned as a great equalizing institution, and its allure was shrouded in the idea that, in theory, everyone was equally subject to state punishment.

In the design of the carceral state, the people "consented" to the prison precisely because society was rooted in the idea of equal deprivation. As Michel Foucault has suggested, the prison was an institution that appeared to equalize the citizenry by taking not always life and limb but certainly time: "How could prison not be the penalty par excellence in a society in which liberty is a good that belongs to all ... ? Its loss has therefore the same value for all; unlike the fine, it is an 'egalitarian' punishment. The prison is the clearest, simplest, most equitable of penalties. Moreover, it makes it possible to quantify the penalty exactly according to the variable of time. There is a wages-form of imprisonment that constitutes, in industrial societies, its economic 'self-evidence'-and enables it to appear as a reparation." ${ }_{99}$ In these "equalizing" deprivations of body and labor time, the prison was given its "self-evident character"-its appearance as "hav[ing] no alternative, as if carried along by the very movement of history." ${ }^{\circ 0}$ The prison, as an idea about a building, drew on this narrative of equality, even as it introduced a form of political membership that could be taken away by the state under the guise of the public.

Although the prison appeared as an equalizing institution, the carceral state was a theory of mass incarceration in the way that it was fundamentally shaped by the principle of less eligibility. By design, the prison was the boundary between status and nonstatus, and it was this line that was engineered to balance utilitarian ideas of the prisoner's pain and the citizen's pleasure. In Bentham's terms, prison 
life was designed to be fundamentally "less eligible" or less desirable than life outside of the prison, so that structured suffering would incentivize returns to the free world and the virtuous behavior of citizens. In the United States, this idea developed out of utilitarian and republican ideologies in the 1770 s, as carceral architects sought to imagine the prison as a border between less eligible lives and a free world governed by the threat of civil death. In its ordering of the carceral gothic, the principle of less eligibility was materialized through the use of intrigue and superstition, as part of a structure that drew the eye of the spectator to the prison house door and then normalized that door as part of the cost of freedom.

The prison was paraded as a democratic institution not only through the gothic memories of whiteness, freedom, and equality but also through the normalization of the gothic in everyday life. In the domestication of gothic architecture between 1830 and 1860, "the gothic" was reintroduced as a feature of the "wealthy home" and came to signal an "upward, aspiring, imaginative feeling" that conveyed economic stability. ${ }^{61}$ Prison designers introduced this version of the gothic in the cities, counties, and townships near gothic penal institutions as a counterimage. John de Haviland himself, along with Benjamin Latrobe and Andrew Jackson Downing, designed gothic homes to be "wonderfully captivating" scenes of "otherworldliness." ${ }^{2}$ The gothic prison and the gothic home were both expressions of sovereignty. The prison was an emblem of the state's power to punish, and the home was a symbol of the castle doctrine, which authorized self-defense on the grounds that the home was a kind of legal castle. The domestication of gothic architecture during the gothic period of prison reform introduced new and everyday ways of experiencing the power of the carceral state. It also reinforced, as a form of "experiential" knowledge of the meaning of the building, the idea of the prison as an institution for bodies with status.

The appeal of the gothic as a democratic image was also sometimes solidified in the architecture of the statehouse. State capitals often reinforced the idea of the prison's relationship to democratic governance by spatially concentrating the meaning of the prison house and the statehouse. In Kansas, the same architect, Erasmus Carr, built the prison and the capital as coequal architectures of the state. Louisiana went so far as to actually build a gothic state capitol, creating between 1852 and 1932 a certain symbiosis between the prison and the state as visual references. Mark Twain in Life on the Mississippi blamed the "little sham castle" on the literary influence of Sir Walter Scott's "medieval romances." ${ }_{3}$ "It is pathetic enough, that a whitewashed castle, with turrets and things-materials all ungenuine within and without, pretending to be what they are not-should ever have been built in this otherwise honorable place," Twain wrote. Although Louisiana was exceptional in designing its statehouse to look like a prison, other states connected the prison to democracy in less visible ways. Arkansas built a new state capitol on the former site of its state penitentiary in 1899, burying "bricks salvaged from the original penitentiary" in "the walls located around the outside 
of the basement of the state capitol." ${ }^{4}$ Connecting mass democracy to mass incarceration through architecture, the gothic statehouse was part of the history of the prison's visual tradition.

The "horrific prison facades" and their domestic counterparts reinscribed state power by recalling a memory that had to be made. Recalling "a time and place that never existed," the prison was an inheritance of gothic bricolage, a coming together of "bits and pieces of various traditions, transformed and superimposed upon a new landscape." ${ }^{\prime 5}$ In the entrance to the prison house door, the state confessed the gothic horror of an unfreedom that lingered in the transition from despotism to democracy. In a political moment in which state power was consolidated in the name of democracy, these sites of legal inversion recalled the gothic design in order to make compatible with democracy a form of punishment that was fundamentally incompatible with democracy. Against this backdrop, Leavenworth became the flagship institution of the carceral state. It was not the origin of the state's carceral capacity -it was the emblem of an already existing federal capacity that had been nurtured in the gothic landscapes of the states. In this shadow carceral state, the long relationship between federal and state prisons was not about federal weakness and state control but about engineering the public embrace of a prison built to look like democracy.

\section{LEAVENWORTH AND THE GOTHIC CARCERAL STATE}

When Leavenworth suggested through architecture that the prison was a democratic institution, it combined Auburn's "five tiers of back-to-back cells ... flanked by long dark corridors" with Pennsylvania's arrangement of the cell houses in a radial pattern. This meant that Leavenworth's cellblocks were arranged like the spokes of a wheel emerging from a lengthy front wall. ${ }^{66}$ In this way, the prison echoed the architecture of the US capital city, which was patterned in 1790 in a mode that later came to look like a prison. Haviland's architecture crossed corridors around a central node in order to form a prison epicenter. With cells emanating from an institutional center, Haviland centralized the prison's power in a theory of rational functionalism that increased its utility in "watching, convenience, economy, and ventilation." ${ }^{67}$ Haviland's vision of centralized power matched the vision of the US federal city. When the French architect Pierre L'Enfant arranged the city's gridlines in 1790, he created "radial patterns imposed on orthogonal streets." 68 These gridlines brought travelers organically to designated sites of commemoration, including statues, plazas, and memorials. L'Enfant placed the coequal branches of the legislature and the executive on two hills, creating a topographic map of the separation of powers. Around these "pedestals" he arranged "twelve wide avenues radiating out from the site like a massive sunburst." ${ }^{69}$ It was a city that reflected centralization and federalized power, and Haviland drew on this framework in articulating the power of the prison. 


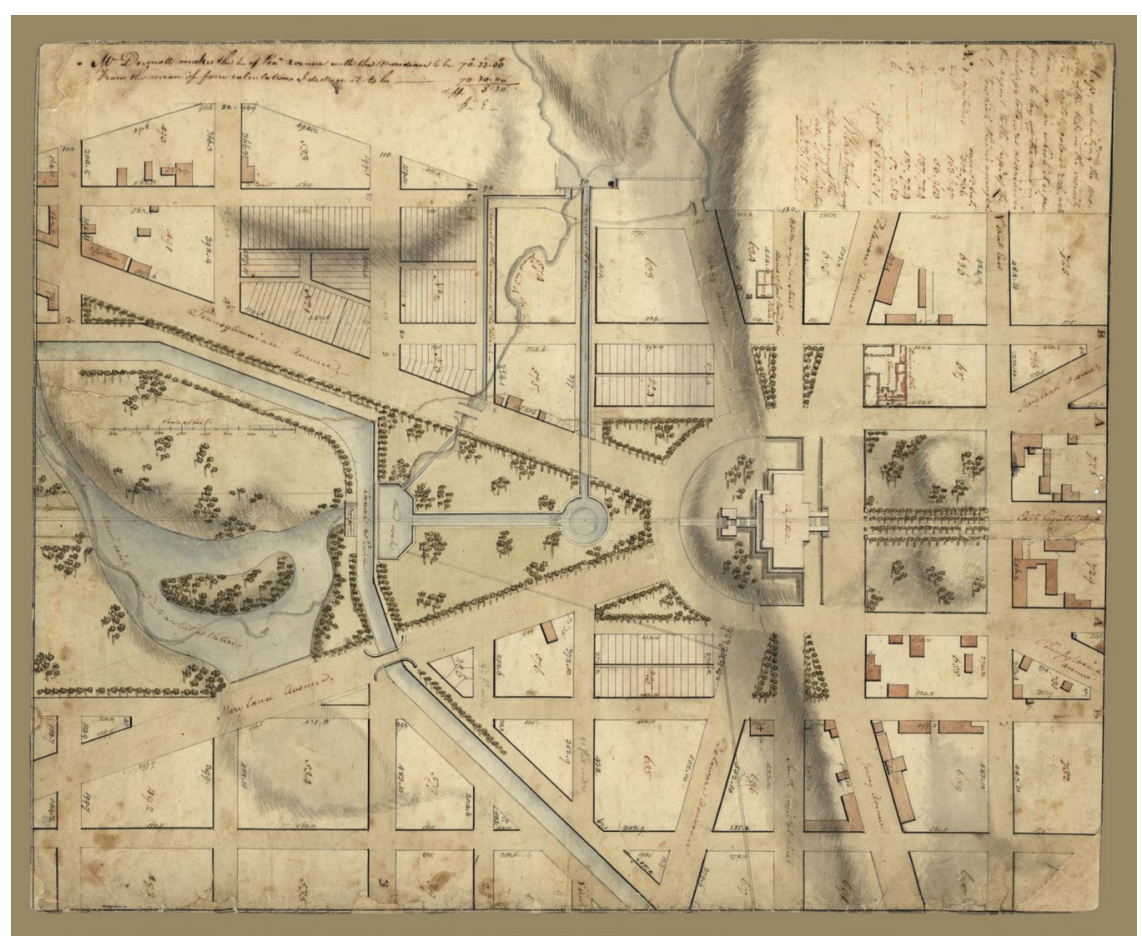

FIGURE 3. Benjamin Henry Latrobe. Map exhibiting the property of the U.S. in the vicinity of the Capitol: colored red, with the manner in which it is proposed to lay off the same in building lots, as described in the report to the Sup't of the city to which this is annexed. 1815. Watercolor on paper. Geography and Map Division, Library of Congress.

Because of the prison's central place in the theory of the American state, it was significant that nearly all of the federal architects between 1790 and 1860 were prison designers. Pierre L'Enfant was replaced by Benjamin Henry Latrobe, who, along with Thomas Jefferson, designed the Virginia State Penitentiary. Latrobe's students included John de Haviland, Robert Mills, and William Strickland. ${ }^{\circ}$ Robert Mills, who was appointed federal architect from 1836 until 1852, designed Louisiana's state prison in the 1820 s. $^{11}$ He later proposed drawings for a jail in Burlington County, New Jersey, and a state prison in South Carolina. ${ }^{72}$ William Strickland designed the Western State Penitentiary in Pennsylvania, which John de Haviland abhorred and was later hired to rebuild. ${ }^{73}$ These architects used radial patterns to connect the prison to the state in a theory of carceral democracy that was rooted in the centralization of power.

The architects of the carceral state were influenced by liberal and utilitarian frameworks that intersected in the idea that the state is obligated to punish its citizens as part of the social contract. In this tradition, individuals in society were 
bound by the exchanges of consent and contract to the state's "penal right." 74 When Thomas Hobbes wrote that one "divests himself of his natural liberty" and joins in civic association, he described membership in the language of "artificial chains, called civil laws, which they themselves, by mutual covenants, have fastened at one end, to the lips of that man, or assembly, to whom they have given the sovereign power; and at the other end to their own ears. These bonds, in their own nature but weak, may nevertheless be made to hold, by the danger, though not by the difficulty of breaking them."75 John Locke's theory of government likewise articulated a subject free from the "inconstant, uncertain, unknown, arbitrary will of another" but compared "freedom of men under government" to putting on "the bonds of civil society." ${ }^{6}$ "The social contract tradition was bound to the prisonized terrain of the state, since it took for granted an "agreement" to submit to state violence. Not just physical but legal violence was at the heart of the contract. The prison therefore represented all of the contradictions of a free society with unfree subjects. It existed in a "dialectical relationship with freedom, as its necessary negation." ${ }^{77}$ Lisa Lowe has suggested in her "unsettling genealogy of modern liberalism" that the boundary between rights-bearing subjects and nonsubjects was "the condition of possibility for Western liberalism, and not its particular exception." ${ }^{8}$ As the "negation of the conditions which allow one to define oneself as a person," the prison was an inversion of political status that was made to make sense through the negative aesthetic of prison architecture. ${ }^{79}$ The prison was the "epistemological project of the Enlightenment" and a betrayal of the free individual it produced, and yet it became the quintessentially "democratic" institution on which the whole house of democracy was built. ${ }^{80}$

Perhaps the prison could be taken for granted in the theory of the liberal state because the United States was seen as a place colonized by criminals. After the American "revolution," the presence of between thirty and fifty thousand prisoners who had been "cast for transportation" to the colonies led to concerns about the prisonized nature of the American landscape.$^{81}$ The revolution itself was described by the British as the work of a "race of convicts," and this identity remained embedded in the course of the new American state. ${ }^{82}$ Even after England turned to Australia to banish its prisoners, Europe's criminals continued to "swarm" the United States under cover of private enterprise. Fearing floods of criminals at the shores, James Cooper of Pennsylvania complained on the Senate floor in 1855 that there was "scarcely an emigrant ship which arrives in our ports that is not, to some extent, freighted with this kind of cargo ... wearing as the badges of their conviction, chains upon their limbs." ${ }^{13} \mathrm{He}$ insisted that Europe had no right to "make of the United States a penal colony" ${ }^{4}$ In 1866, Charles Sumner stood on the Senate floor holding a German newspaper detailing the practice of transportation to the United States as a substitute for domestic punishment. ${ }^{85}$ As a response, the 1875 Page Law banned "persons ... undergoing sentence for conviction in their own country of felonious crimes other than political." ${ }^{\text {" }}$ In 1896 , a unanimous Senate resolution directed immigration authorities to "inquire 
whether or not any legislation is necessary to prevent the introduction into the United State of aliens imprisoned in penal colonies of European nations." ${ }^{87}$ This idea of criminals at the borders, which lasted for generations, transformed the association between prisons and democracy, federalizing the matter of crime and setting in motion routine increases in carceral capacity because of a nation in need of mass punishment.

In this context of national anxiety about endemic crime, the placement of a flagship institution at the center of the nation was yet another moment in the institutional development of the carceral state rather than the mark of its origins. That institutional development accelerated after 1887, when Congress prohibited states from selling the labor of federal prisoners in state institutions to private entrepreneurs. This led to tensions between federal and state authorities over prison profitability as the number of federal prisoners increased from forty-eight in 1846 to several hundred by 1880 and more than two thousand by $1896 .^{88}$ The political push for a new federal prison gained support in the late 188 os when five former presidents, three attorneys general, and countless public interest groups campaigned for the building of a new federal institution to replace the "antiquated and inefficient" system of scattering federal prisoners to the states. ${ }^{89}$ This scattering is often interpreted as a sign of federal weakness rather than a function of intergovernmental power guided by federal policy. According to the theory of American statelessness, the federal government went one hundred years without the institutional resources to house its own prisoners.

In moving from the "weak state" framework to a theory of intergovernmental power through the lens of geography and culture, it becomes critically important that it was the Billon Dollar Congress, the first northern/Republican-controlled Congress since the end of Reconstruction, that consolidated federal authority over matters of punishment with the passage of the Three Prisons Act. The Three Prisons Act (1891) required that three prisons be built-one in the West, one in the center, and one in the East-to serve a unifying function in a prison system that differed across regions and local justice cultures. The original legislation called for two prisons on either side of the North-South border to serve as models of penitentiary reform, particularly for southern institutions - those "inhuman, unchristian, if not murderous" institutions in which "some state scandals . . have shocked the whole public conscience of the country" ${ }^{\circ}$ In response to the North-South orientation of congressional debate, Representative Thomas J. Clunie (D-CA) gave an impassioned plea for law and order in the West. His argument, frequently interrupted by applause, insisted that western states deserved a federal prison in honor of their status as full members of the Union. He argued that this equal distribution of American prisons was a question of democracy:

We are like the rest of the country; we have our criminal classes, requiring prisons for their confinement. We are a part of this great Republic.... We have been treated in the past as if we were not a part ... of this great nation.... We have no public 
buildings worthy of note. Our rivers and harbors have been neglected by the General Government. .. . Now ... we are told that none of our prisoners convicted in the territory west of the Rocky Mountains shall be committed to the prisons ... established under this act. ... In all fairness to the people of the great empire west of the Rocky Mountains, ought not their rights be considered in this legislation? ... We are willing to give you a prison north and south, and we claim, as a matter of justice to the entire Pacific Coast, that a prison should also be located west of the Rocky Mountains.... It should be our aim to place all the great States and Territories of this nation on an equal footing. ... I appeal to this House for justice. ${ }^{91}$

Clunie's appeal resulted in the rearrangement of the nation's political geography: in addition to Leavenworth at the center, the prison of the East would be built in Atlanta, while the prison of Clunie's dreams was fashioned from a converted territorial prison on McNeil Island in Washington..$^{92}$ Because the Three Prisons Act was given no supporting appropriation, federal prisoners remained scattered among the various state, territorial, and military prisons, with over 500 prisoners at Fort Leavenworth and 2,500 in thirty state prisons. ${ }^{93}$

When federal funds were secured in 1896, the government withdrew some of its prisoners from gothic institutions and began the largest prison construction project in US history. The result was a carceral complex that reached radially from Leavenworth to Atlanta and from Leavenworth to McNeil Island. Those lines also extended in theory from the capital, and to the long traditions of penal federalism and carceral citizenship that had originated in the gothic prison towns of the nineteenth century. The reach of intergovernmental power into those places generated a kind of cultural allegiance to the prison as an idea about state governance. In the context of this carceral citizenship, the public clamor for Leavenworth came from grand juries and city councils in St. Louis, Augusta, Huntsville, Chattanooga, and Dallas, where citizens gathered and passed resolutions to locate Leavenworth in their jurisdictions.${ }^{94}$ In letters to the attorney general, federal prisoners and guards in state institutions requested transfers and promises of employment, while judges, reformers, and architects advised that the prison be built in their districts. ${ }^{95}$ Others invited themselves into the structure of Leavenworth by offering to build the prison, mostly in places where the boom in prison construction over the course of the nineteenth century had already created a kind of local prison-industrial complex. Railroad companies, merchants, and steel companies specializing in prison architecture wrote to the attorney general to offer presentations on "available models" of steel cages. The Stewart Jail Works Company in Cincinnati notified the federal government of its specialization in "tool proof steel construction, operating devices, and prison locks." ${ }^{96}$ These companies were so busy in this early moment in the history of mass incarceration that Adam's Steel and Wireworks Prison and Jail Construction of Joliet, Illinois, wrote that they would be able to show the Department of Justice only a "one-half size working model of two cell fronts designed especially for concrete construction," because the full model was currently on display at the Minnesota State Prison in Stillwater. ${ }^{97}$ 


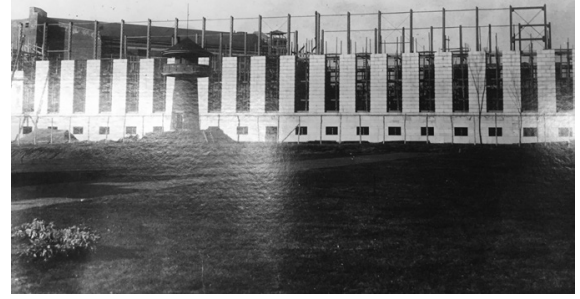

FIGURE 4. US Penitentiary, Leavenworth, Kansas. "View of Partially Constructed East Cell Building." Album of Views of United States Penitentiaries at Atlanta, Georgia and Fort Leavenworth, Kansas, circa 1900-circa 1925. Record Group 129, Still Photographs, National Archives II, College Park, Maryland.

Despite the folklore often repeated by the prison's historians that the federal prison system was "weak" before the Bureau of Prisons was established in 1930, the prior strength of the federal carceral state was evidenced in its ability to mark the bodies of its prisoners. In Allison Poe's 1910 book on the reach of the carceral state, he documented the prison's institutional power: "You stand handcuffed to the steel door ten hours a day. ... Everywhere you look, you are reminded that you are a convict, and that you are in the U.S. Penitentiary. Guards have 'U.S.P.' on the lapels of their coats, 'U.S.P.' is stamped upon the harness, upon the wheelbarrows . . . ; in fact, you cannot look at anything without seeing 'U.S.P.' stamped on it. You are constantly being reminded of the fact that you are a U.S. prisoner."98 The scale of Leavenworth's operation in the years when federal control was supposed to lack institutional capacity is astounding. In the prison's archive, a 1910 expenditure list appended to a typed appropriations document shows the scale of Leavenworth's economic reach:

For miscellaneous expenditures ... for fuel, forage, hay, light, water, stationery . . . hay and straw for bedding; blank books, blank forms, type-writing supplies, pencils and memorandum books for guards, books for use in chapel, paper, envelopes, and postage stamps for issue to prisoners; for labor and materials for repairing steam-heating plant, electric plant and water circulation, and drainage; for labor and materials for construction and repair of buildings; for general supplies, machinery, and tools for use on farm and in shops, brickyards, quarry, limekiln, laundry, bathrooms, printing office photograph gallery, stables, policing buildings and grounds; for the purchase of cows, horses, mules, wagons, harness, veterinary supplies, lubricating oils, office furniture, stoves, blankets, bedding, iron bunks, paints and oils, library books, newspapers, and periodicals, electrical supplies; for payment of water supply, telegrams, telephone service, notarial and veterinary services, for advertising in newspapers; for fees to consulting physicians called to determine mental condition of supposed insane prisoners, and for other services in cases of emergency; for pay of extra guards when deemed necessary by the Attorney General, and for expense of care and medical treatment of guards who may be injured by prisoners while said guards are endeavoring to prevent escapes, or suppressing mutiny, forty thousand dollars. ${ }^{99}$ 
In the blank and preprinted forms of a state that anticipated mutiny, injury, and insanity, the state's carceral capacity was in fact already iconic by the early 1900 s. It circulated as an idea in popular culture, in postcard images like the one featured on the book's cover, and in the threat of getting sent "up river" to the Big House.

Leavenworth was an intervention in earlier prison archetypes, and it departed radically from the long tradition of building prisons as obvious illustrations of deprivation. Its facade nevertheless concealed an important gothic subtext: the limestone that gave the building its "federal" look was in fact layered on top of an already existing brick wall, which made it functionally unnecessary except in the presentation of its argument. What the reader of this building could not see was Leavenworth's dungeon-the six unlit, triangular solitary cells detached from the main administrative building. They were designed this way to prevent comfort in sitting or standing. In addition to the dark cells, Building 63 housed the isolation cells, where prisoners either broke rock or were chained in stress positions. The deprivations of infamy included a ball and chain, sometimes called the Oregon Boot, a fifteen-pound shackle bolted around the leg that over time caused the loss of muscle control. Prisoners from this period in the prison's history report brutal physical violence, prolonged sensory deprivation, starvation, the application of shocks through electrical batteries, and even the pumping of ammonia gas into the cells. ${ }^{100}$ After Thomas Kating smuggled a twenty-page letter to President Woodrow Wilson in 1913, the socialist newspaper Appeal to Reason began a series of investigations into the use of sexualized violence, electrical shock, and the beating death of Clarence Maitland at the hands of the deputy warden in a prison it described as an "instrument of torture." ${ }^{101}$ James Bennett, who later became director of the Bureau of Prisons, confirmed the violence, recalling that on his first visit to the institution he saw "men . . . routinely strung up by the thumbs, handcuffed to high bars, kept for weeks in solitary confinement on bread and water . . . whipped, paddled, and spanked, spread-eagled in the hot sun, locked up in sweatboxes, confined in tiny spaces where they can neither sit nor stand." ${ }^{102}$ The subsequent reports of federal investigators entering federal prisons read like the earlier generation of state reports that indexed the violence of the carceral gothic. Leavenworth had already become an epicenter of carceral violence.

Against the backdrop of routinized brutality, Public Law 71-218 established the Federal Bureau of Prisons not because federal prisons were perceived as "weak" institutions with little power but because Congress wanted to reign in the power of the wardens. There were already fourteen federal prisons and thirteen thousand prisoners by 1930, and Public Law 71-218 appointed a director of the bureau to improve the "safe-keeping, care, protection, instruction, and discipline" of federal prisoners. ${ }^{103}$ It required that federal prisoners be employed and that escaping fugitives be punished with an additional five-year sentence. It criminalized bringing drugs and weapons into a federal prison, which now carried a sentence of "not more than ten years." Systematizing the carceral state brought about another 
boom in federal prison construction, and by the end of 1940 the federal apparatus had grown to twenty-four prisons and nearly twenty-five thousand prisoners. As part of New Deal state building, an "Advance Planning Unit" was created within the Bureau of Prisons in 1949, which significantly accelerated prison growth in the United States by developing a "reservoir of blueprints and details for the construction of penal and correctional institutions." ${ }^{104}$ These plans "were to be held in reserve and ready for immediate use in the event economic conditions were such as to require a nationwide public works program."105 As a catalog of the prison's future, the unit's Handbook of Correctional Institution Design and Construction, which was printed by Leavenworth's prisoners, offered a blueprint for mass incarceration that was imaginable only because of the long arc of federal power.

Leavenworth was a critical moment in the centralization of state power, one that redefined the course of the federal prison system and nationalized the meaning of punishment. It stands today as a largely unread text. Its radial reach across the landscape nevertheless signifies a moment between gothic and minimalist trends in prison architecture and a moment when the prison system was defined by intergovernmental power and a shared commitment to law and order. Because Leavenworth promised to depart from the violence of the carceral gothic but ultimately returned to state terror as its founding project, it now crowns the very gothic institutions it was designed to end. Some of these institutions, like the Kansas prison, remain in operation in its shadows, while others, like Pennsylvania, have become crumbling, timeless artifacts of another era. Haviland's Eastern State leaves today's visitors "both awestruck and confused by the incomprehensible architecture."106 Despite these problems with translation, the meaning of carceral democracy, in all of its cultural details, remains etched on the surface of the buildings. In the shape of the prison house door, architects recorded a theory of a carceral state that was grounded in violence and relied on the institution of civil death. 